\title{
Copyright in the EU: In Search of (In)Flexibilities
}

\author{
by Eleonora Rosati*
}

\section{The Rules of (EU) Attraction}

Over the past few years consensus has grown around the idea that current EU legislative framework for copyright lacks the flexibility needed to accommodate emerging interests, specifically those arising in connection with technological development. The principal directive in the area of copyright - Directive 2001/29/EC (the 'InfoSoc Directive') $-{ }^{1}$ purported to harmonise, among other things, the main exclusive rights (reproduction, communication and making available to the public, and distribution) by providing a "high level of protection", ${ }^{2}$ and the system of related exceptions and limitations. Yet the Directive has been widely criticised for having failed to increase legal certainty in the $\mathrm{EU}^{3}$ and, overall, has been considered " $a$ badly drafted, compromise-ridden, ambiguous piece of legislation". ${ }^{4}$ While debate as to whether the InfoSoc Directive - in particular, Article 5 and its enumerated system of exceptions and limitations - should be reformed has gained momentum, ${ }^{5}$ very limited (if any) attention has been devoted to exploring the relationship between this directive, the emerging doctrine of EU pre-emption and the room left for national initiatives. In particular, it remains uncertain to what extent Member States are free to legislate in areas affected by the InfoSoc Directive, notably exclusive rights and related exceptions and limitations. Therefore, two main questions should be addressed: Are Member States entitled to alter, ie broaden or restrict, the scope

\footnotetext{
* Ph.D. (EUI), LL.M. (Cantab). Email: eleonorarosati@gmail.com. I am truly grateful to Professor Lionel Bently (University of Cambridge), Cédric Manara and William F. Patry (Google), and Professor Jeremy Phillips (Queen Mary, University of London) for their comments on an earlier draft. Errors and omissions remain my own.

${ }^{1}$ Directive 2001/29/EC of the European Parliament and of the Council of 22 May 2001 on the harmonisation of certain aspects of copyright and related rights in the information society, O.J. 2001, L 167, 10-19.

${ }^{2}$ See Case C-5/08 Infopaq International A/S v. Danske Dagblades Forening, [2009] ECR I-06569, 16 July 2009, para 40, in which the Court of Justice of the European Union indicated this as the main objective of Directive 2001/29/EC.

${ }^{3}$ See Guibault and Others, Study on the implementation and effect in Member States' laws of Directive 2001/29/EC on the harmonisation of certain aspects of copyright and related rights in the Information Society (2007), available at tinyurl.com/patlevz, 166-167.

${ }^{4}$ Hugenholtz, "Why the Copyright Directive is unimportant, and possibly invalid" (2000) 22(11) EIPR 499, 500.

${ }^{5}$ A public consultation on the review of EU copyright rules was launched in late 2013: see European Commission, "Public Consultation on the Review of EU Copyright Rules" (2013), available at tinyurl.com/q2bodlj.
} 
of the exclusive rights harmonised by the InfoSoc Directive? May Member States decide (as the UK did) not to transpose the full language of exceptions and limitations once they chose to implement a certain exception or limitation from Article 5 catalogue into their national laws?

It is submitted that the answer should be in the negative in both cases.

Following consideration of the little-theorised - yet increasingly applied - doctrine of EU preemption, an examination of relevant decisions of the Court of Justice of the European Union (CJEU) will be undertaken. This case law demonstrates that, in areas specifically harmonised by the InfoSoc Directive, Member States are - and therefore should be - less free to legislate autonomously than what has been so far understood. In addition, relevant provisions of the InfoSoc Directive are in unequivocal terms and impose unconditional (precise) obligations as to the result to be achieved. This means that, where a certain Member State has failed to implement the directive correctly, national courts are free to ignore the conflicting provisions in question.

This contribution focuses on the InfoSoc Directive, and is structured as follows: Part 1 summarises the main goals that the EU wished to fulfil by adopting Directive 2001/29/EC. Among other things, these included enhancing the internal market, by removing barriers to free movement of goods and services and distortions to competition, and promoting legal certainty. Part 2 discusses the doctrine of EU pre-emption. Part 3 considers the case of exclusive rights, in light of relevant CJEU decisions, notably Cases C-277/10 Luksan, ${ }^{6}$ and C-604/10 Football Dataco. ${ }^{7}$ This case law suggests that Member States may not alter the scope of harmonised exclusive rights. Part 4 discusses the case of exceptions and limitations, especially in light of CJEU judgments in Cases C-467/08 Padawan $^{8}$ and C-510/10 TV2 Danmark, ${ }^{9}$ and submits that - contrary to relevant practice at the national level - Member States were actually required to transpose the language of the chosen exceptions and limitations verbatim, unless where otherwise provided. In the latter case, Member States have retained a certain legislative freedom. However, as the CJEU confirmed in Case C-145/10 Painer, ${ }^{10}$ this must be exercised within the boundaries of EU law and the overarching limit of Article 5(5) of Directive 2001/29/EC. In light of UK experience, Article 5 'inflexibility' would prevent restrictive national implementations of the InfoSoc system of exceptions and limitations. Part 5 considers the case of exclusive rights that have not been expressly harmonised by the InfoSoc Directive, eg the right of adaptation, and assesses to what extent Member States are free to legislate in this regard - including related exceptions and

\footnotetext{
${ }^{6}$ Case C-277/10 Martin Luksan v. Petrus van der Let, [not yet published], 9 February 2012.

${ }^{7}$ Case C-604/10 Football Dataco Ltd. and Others v. Yahoo! UK Ltd. and Others, [not yet published], 1 March 2012.

${ }^{8}$ Case C-467/08 Padawan SL v. Sociedad General de Autores y Editores de España (SGAE), [2010] ECR I-10055.

${ }^{9}$ Case C-510/10 DR and TV2 Danmark A/S v. NCB - Nordisk Copyright Bureau, [not yet published], 26 April 2012.

${ }^{10}$ Case C-145/10 Eva-Maria Painer v. Standard VerlagsGmbH and Others [not yet published], 1 December 2011.
} 
limitations - in compliance with relevant obligations under EU and international laws. Part 6 notes that domestic law must be interpreted in light of the wording and purpose of Directive 2001/29/EC, and discusses the possible legal consequences of incorrect national transpositions of the Directive.

\section{Rationale and Objectives of the InfoSoc Directive}

By adopting the InfoSoc Directive, the EU intended to achieve two main objectives. The first one was to align EU copyright law with and implement into EU legal order the WIPO Internet Treaties. ${ }^{11}$ In particular, the WIPO Copyright Treaty requires compliance with Articles 1 to 21 of the Berne Convention. Thus, by adopting the InfoSoc Directive, the EU deprived Member States of their competence to implement the relevant provisions of the Berne Convention. The second objective was to harmonise certain aspects of substantive copyright law, in line with the agenda that the Commission had set in its 1995 Green Paper ${ }^{12}$ and 1996 Follow-up. ${ }^{13}$ These had somehow marked a departure from earlier policy of piecemeal approximation. ${ }^{14}$ Overall, it was felt that, without harmonisation at the (then) Community level, national legislative initiatives would result in significant differences in protection and thereby in restrictions on the free movement of services and products incorporating, or based on, intellectual property (IP). ${ }^{15}$ In particular, diverging approaches at the national level would cause legal uncertainties and lead to a re-fragmentation of the internal market. ${ }^{16}$ Ultimately, the impact of legislative differences and uncertainties between Member States would hinder economies of scale for new products and services. ${ }^{17}$ Hence, not only should the EU harmonise certain aspects of copyright and related rights, but also inconsistent national legislative responses to technological developments should be avoided. ${ }^{18}$ This would be also necessary "to ensure that competition in the internal market is not distorted as a result of differences in the legislation of Member States." ${ }^{19}$ This said, the InfoSoc

\footnotetext{
${ }^{11}$ Recital 15.

${ }^{12}$ Commission of the European Communities, "Green Paper on Copyright and Related Rights in the Information Society", COM(95) 382 final. The issue of copyright exceptions and limitations was only incidental to this document, as noted by Hugenholtz, "Why the Copyright Directive is unimportant", cit., 500.

${ }^{13}$ Commission of the European Communities, "Communication from the Commission: Follow-Up to the Green Paper on Copyright and Related Rights in the Information Society", $\operatorname{COM}(96) 568$ final.

${ }^{14}$ Hugenholtz, 'Why the Copyright Directive is unimportant', cit., 499.

${ }^{15}$ Recital 6.

${ }^{16}$ Recital 7.

${ }^{17}$ Recital 6.

${ }^{18}$ Recital 7.

${ }^{19}$ Case C-510/10 TV2 Danmark, cit, para 35, referring to Case C-479/04 Laserdisken ApS v. Kulturministeriet, [2006] ECR I-8089, para 26 and paras $31-34$
} 
Directive is expressly without prejudice to the law of contract, ${ }^{20}$ moral rights, ${ }^{21}$ and leaves unaffected earlier directives that harmonised specific aspects of copyright and related rights, ${ }^{22}$ including Directives 2009/24/EC, ${ }^{23}$ 2006/115/EC, ${ }^{24}$ 2006/116/EC, ${ }^{25}$ 93/83/EEC, ${ }^{26}$ and 96/9/EC. ${ }^{27}$

Following adoption of the InfoSoc Directive, what has remained uncertain (and has also received limited consideration) is to what extent Member States have remained free to legislate autonomously, both in respect of the rights harmonised therein and their related exceptions and limitations.

\section{The Doctrine of EU Pre-Emption}

Determination of national legislative freedom in areas affected by EU directives requires consideration of the rather embryonic doctrine of EU pre-emption, which is (somehow) codified ${ }^{28}$ in Article 2(1-2) Treaty on the Functioning of the European Union (TFEU): ${ }^{29}$

"1. When the Treaties confer on the Union exclusive competence in a specific area, only the Union may legislate and adopt legally binding acts, the Member States being able to do so themselves only if so empowered by the Union or for the implementation of Union acts.

2. When the Treaties confer on the Union a competence shared with the Member States in a specific area, the Union and the Member States may legislate and adopt legally binding acts in that area. The Member States shall exercise their competence to the extent that the Union has not exercised its competence. The Member States shall again exercise their competence to the extent that the Union has decided to cease exercising its competence."

\footnotetext{
${ }^{20}$ Art. 9.

${ }^{21}$ Recital 19.

${ }^{22}$ Art. 1(2). Hart, “The Copyright in the Information Society Directive: an overview" (2002) 24(2) EIPR 58, 58, argued that this had the potential to create some serious inconsistencies in the treatment of copyright subject-matter.

${ }^{23}$ Directive 2009/24/EC of the European Parliament and of the Council of 23 April 2009 on the legal protection of computer programs (Codified version), O.J. L 111, 16-22.

${ }^{24}$ Directive 2006/115/EC of the European Parliament and of the Council of 12 December 2006 on rental right and lending right and on certain rights related to copyright in the field of intellectual property (Codified version), O.J. L 376, 28-35.

${ }^{25}$ Directive 2006/116/EC of the European Parliament and of the Council of 12 December 2006 on the term of protection of copyright and certain related rights (Codified version), O.J. L 372, 12-18.

${ }^{26}$ Council Directive 93/83/EEC of 27 September 1993 on the coordination of certain rules concerning copyright and rights related to copyright applicable to satellite broadcasting and cable retransmission, O.J. L 248, 15-21.

${ }^{27}$ Directive 96/9/EC of the European Parliament and of the Council of 11 March 1996 on the legal protection of databases, O.J. L 77, $20-28$

${ }^{28}$ Chalmers - Davies - Monti, European Union Law, $2^{\text {nd }}$ edn (CUP, 2010), 206.

${ }^{29}$ Treaty on the Functioning of the European Union (Consolidated version 2012), O.J. C 326, 47-200.
} 
Although no express reference to this doctrine was made in the case law of the CJEU prior to the 2009 Opinion of Advocate General (AG) Colomer in the Budweiser case, ${ }^{30}$ since the early $1980 \mathrm{~s}^{31}$ debate around EU pre-emption has increasingly gained momentum, and has indeed developed in parallel to what appears a clearer discussion around supremacy of EU law. The assimilation of pre-emption problems to supremacy questions has been indicated as the main reason for the under-theorised nature of the pre-emption phenomenon. ${ }^{32}$ Although related, the two doctrines remain in fact distinct:

"Supremacy denotes the superior hierarchical status of the Union legal order over the national legal orders and thus gives European law the capacity to preempt national law. The doctrine of preemption, on the other hand, denotes the actual degree to which national law will be set aside by European law." 33

Drawing from US experience,$^{34}$ three general categories of pre-emption have been identified in EU law. ${ }^{35}$ The first one is 'field' pre-emption, which applies where EU law has an exclusive competence in a certain area: national laws may be enacted only with the authorisation of EU law. The second category is 'rule' pre-emption, which is relevant to areas in which EU law and Member States share competences: national measures may be adopted but these will be set aside if they conflict with EU law. The third type is 'obstacle' pre-emption: Member States are free to legislate in certain areas, but must not adopt measures that obstruct the effectiveness of EU policies. In US constitutionalism, the latter has proved the most elusive to define, especially if it is taken to displace "any state legislation which frustrates the full effectiveness of federal law". ${ }^{36}$

\footnotetext{
${ }^{30}$ Case C-478/07 Budějovický Budvar, národní podnik v. Rudolf Ammersin GmbH [2009] ECR I-07721, Opinion of Advocate General Ruiz-Jarabo Colomer delivered on 5 February 2009, in particular para 93: "What we have here ultimately is the debate about Community 'pre-emption' of a measure and the situations in which the concurrent competences of the Member States in a particular field may have been displaced by the activity of the Community legislature."

${ }^{31}$ Weiler, “Community, Member States and European integration: is the law relevant?" (1982) 21 J Common Mkt Stud 39.

${ }^{32}$ Schütze, European Constitutional Law (CUP, 2012), 364.

${ }^{33}$ Ibid. (emphasis in the original text).

${ }^{34}$ Pacific Gas \& Elec. Co. v. State Energy Resources Conservation and Development Comm'n, 461 U.S. 190 (1983).

${ }^{35}$ Schütze, "Supremacy without pre-emption? The very slowly emergent doctrine of Community pre-emption" (2006) 43 CML Rev $1023,1038$.

${ }^{36}$ Ibid., referring to Perez v. Campbell, 401 U.S. 637 (1971), para 652.
} 
Following adoption of the Lisbon Reform Treaty, ${ }^{37}$ supremacy of EU law might have become even more stringent in areas in which the EU and Member States share powers. Within the old EC legal order, supremacy of EU law meant disapplication (not invalidation) of conflicting national laws. Current wording of Article 2(2) TFEU might imply an interpretation in the German federal sense, ie that Article 2(2) TFEU might be used as a platform to strengthen the normative potency of EU law and permit to void national legislation. The result would be that, to the extent that the EU exercises its shared powers, Member States would lose their very competence to legislate autonomously in that particular area. ${ }^{38}$

IP is an area in which the EU has no exclusive internal competence. Also pursuant to AG Colomer's understanding of pre-emption, the enactment of a piece of EU legislation should be such as to prevent national law-making in the area concerned or result in the disapplication (or even invalidation) of preexisting conflicting national laws. ${ }^{39}$ In relation to copyright, it is thus arguable that, except where expressly allowed, Member States might be unable to legislate in areas affected by EU directives ('rule' pre-emption) or, at least, adopt measures that would hinder the effectiveness of EU policies ('obstacle' pre-emption). Overall, as will be seen below, while pre-emption in copyright may be seen as favouring rigidity - rather than flexibility - of legal systems across the EU, this is necessary to achieve the overall objective of establishing a barrierless internal market and ensure the free circulation of copyright-protected goods and services.

\section{EU Pre-Emption and InfoSoc Exclusive Rights}

Articles 2,3 and 4 of the InfoSoc Directive provide a harmonised understanding of the rights of reproduction, communication and making available to the public, and distribution. With regard to reproduction, the Directive merely states that definition of the acts covered by this right should be broad, done in conformity with the acquis communautaire, and refer to a work or a part thereof..$^{40}$ The Directive is more eloquent with regard to the rights of communication and making available to the public. These rights should be understood broadly and intended to cover all communications to the public not present at the place where the communication originates, ${ }^{41}$ and all acts of making available protected subject-matter to members of the

\footnotetext{
${ }^{37}$ Treaty of Lisbon amending the Treaty on European Union and the Treaty establishing the European Community, signed at Lisbon, 13 December 2007, O.J. C 306, 1-229.

${ }^{38}$ See Schütze, 'Lisbon and the federal order of competences: a prospective analysis' (2008) 33(5) E L Rev 709, 716, who however rejects this conclusion.

${ }^{39}$ Arena, "The doctrine of Union pre-emption in the E.U. internal market: between Sein and Sollen" (2011) 17 Colum J Eur L 477, 484.

${ }^{40}$ Recital 21. On the notion of reproduction of a work in part or as a whole, see Case C-5/08 Infopaq, cit., paras 31-38.

${ }^{41}$ Recital 23.
} 
public not present at the place where the act of making available originates. Recital 24 further clarifies that the right to make available to the public should not cover any other acts. The right of distribution is defined as the exclusive right to authorise or prohibit any form of distribution to the public of an original work or its copies by sale or otherwise. The Directive also deals extensively with issues of exhaustion, by preventing among other things - its applicability to the rights of communication and making available to the public, as well as limiting it to tangible copies in relation to the right of distribution. ${ }^{42}$

While there seems to be consensus that the list of exclusive rights harmonised by the InfoSoc Directive is "by no means exhaustive", ${ }^{43}$ it remains doubtful to what extent the rights of reproduction, communication and making available to the public, and distribution have been harmonised by the Directive, and may pre-empt national initiatives.

\subsection{The References in Svensson and C More Entertainment: May Member States Broaden the Scope of the Right of Communication to the Public?}

The recent (still pending) references for a preliminary ruling from the Swedish Svea hovrätt in Case C466/12 Nils Svensson and Others v. Retreiver Sverige AB, and Högsta domstolen in Case C-279/13 C More Entertainment $A B v$. Linus Sandberg have attracted considerable attention, both at the level of national courts ${ }^{44}$ and academic and policy circles. ${ }^{45}$ This has mainly focused on the question whether the expression 'communication to the public', within the meaning of Article 3(1) of the InfoSoc Directive, includes measures to make available on a website open to the public a clickable link to a work broadcast by the relevant copyright holder. Significantly less consideration has been devoted to the other questions, in particular the following:

"Is it possible for a Member State to give wider protection to authors' exclusive right by enabling 'communication to the public' to cover a greater range of acts than provided for in Article 3(1) of

\footnotetext{
${ }^{42}$ It should be noted that, following the CJEU decision in Case C-128/11 UsedSoft GmbH v. Oracle International Corp., [not yet published], 3 July 2012 (this was a case concerning the interpretation of Directive 2009/24/EC), it is currently being debated whether this may be still a correct interpretation of the InfoSoc Directive: see Rosati, "Does exhaustion apply to works other than software? Here's a Katpoll", The IPKat, 28 June 2013.

${ }^{43}$ Ohly, "Economic Rights", in Derclaye (ed.) Research Handbook on the Future of EU Copyright (Edward Elgar Publishing, 2009), 236. See below, sub $\$ 5$.

${ }^{44}$ Paramount Home Entertainment International Limited and Others v. British Sky Broadcasting Limited and Others, [2013] EWHC $3479(\mathrm{Ch})$, in particular paras 29 and 32.

${ }^{45}$ European Copyright Society, The Reference to the CJEU in Case C-466/12 Svensson (2013), available at tinyurl.com/c9qubgn; Association Littéraire et Artistique Internationale (ALAI), Report and Opinion on the making available and communication to the public in the internet environment - focus on linking techniques on the Internet (2013), available at tinyurl.com/obxzhak.
} 
Directive 2001/29/EC of the European Parliament and of the Council of 22 May 2001 on the harmonisation of certain aspects of copyright and related rights in the information society?"

It is submitted that the answer should be in the negative. Should the response of the CJEU differ, not only this would go against Recital 23 of the Directive, but would also contradict the rationale and objectives of the InfoSoc Directive, thus impairing the level playing field that the EU intended to establish by harmonising copyright exclusive rights. Above all, should a Member State conceive the right of communication as covering a broader number of acts as those codified in the InfoSoc Directive, this would result in the reinstatement of those barriers to the free circulation of goods and services that the adoption of the InfoSoc Directive intended to remove. Ultimately, effectiveness of EU action in the area of copyright would be negatively affected, in contrast with the doctrine of EU pre-emption. This conclusion appears supported also by recent decisions of the CJEU, which suggest that Member States may neither restrict nor broaden the scope of exclusive rights.

\subsection{CJEU Case Law Suggests that InfoSoc Exclusive Rights May Not Be Altered}

In its 2012 decision in Case C-277/10 Luksan, the CJEU considered whether an Austrian law that provided that all exclusive exploitation rights in a film vested in its producer and not also in its principal director, as is instead under relevant EU directives, was compliant with EU law. The Austrian Government had relied on Article 14bis(a) of the Berne Convention to advance the proposition that ownership of copyright in a cinematographic work is a matter for legislation in the country where protection is claimed. The CJEU recalled that, by adopting the InfoSoc Directive, the EU implemented the WIPO Copyright Treaty, which as mentioned - requires compliance with Articles 1 to 21 of the Berne Convention. ${ }^{46}$ Although membership of the EU does not affect the international obligations of individual Member States, ${ }^{47}$ when an international instrument allows - but does not require - a Member State to adopt a measure that appears contrary to EU law, that Member State must refrain from adopting such a measure. ${ }^{48}$ This being so, the Court concluded that:

\footnotetext{
${ }^{46}$ Case C-277/10 Luksan, cit., para 59. See also Joined Cases C-403/08 and C-429/08 Football Association Premier League and Others v. QC Leisure and Others, [2011] ECR I-09083, para 189, and the case law cited therein, and below, sub $\$ 4.3$.

47 See Art. 351 TFEU.

${ }^{48}$ Case C-277/10 Luksan, cit., para 62.
} 


\begin{abstract}
"In providing that the principal director of a cinematographic work is to be considered its author or one of its authors, the European Union legislature exercised the competence of the European Union in the field of intellectual property. In those circumstances, the Member States are no longer competent to adopt provisions compromising that European Union legislation. Accordingly, they can no longer rely on the power granted by Article 14bis of the Berne Convention." 49
\end{abstract}

The CJEU added that a national law that deprives creators of their exploitation rights contrary to relevant directives would not only be incompatible with the objective of the InfoSoc Directive of guaranteeing that authors enjoy a high level of protection (Recital 9), ${ }^{50}$ but would be also tantamount to a deprivation of authors' own (intellectual) property. As such, it would represent a breach of Article 17(2) of the Charter of Fundamental Rights of the European Union. ${ }^{51}$

The decision in Luksan suggests that, following EU intervention in respect of certain exclusive rights, Member States would be no longer able to legislate autonomously in such area, eg by restricting (as it was the case here) authors' exclusive rights, even should this faculty be recognised by international instruments like the Berne Convention or the WIPO Copyright Treaty.

Another relevant instance in which the CJEU considered the room left for independent national legislative initiatives was Case C-604/10 Football Dataco. This reference for a preliminary ruling from the Court of Appeal of England and Wales sought guidance, among other things, as to whether Directive 96/9/EC (the 'Database Directive') precludes national legislation that would provide copyright protection under conditions that differ from those set in its Article 3(1). Similarly to the InfoSoc Directive, Directive 96/9/EC was aimed at removing existing differences between national legislations on the legal protection of databases (particularly as regards the scope and conditions of copyright protection), that would adversely affect the functioning of the internal market, the free movement of goods or services and the development of an information market within the EU. ${ }^{52}$ To this end, this directive carried out a harmonisation of the criteria for determining whether a database is protected by copyright. This being so, the Court held that, subject solely to Article 14(2), Directive 96/9/EC precludes national legislation that grants databases copyright protection under conditions that differ from those set out in its Article 3(1). ${ }^{53}$

\footnotetext{
${ }^{49}$ Ibid., para 64.

${ }^{50}$ Ibid., para 66.

${ }^{51}$ Ibid., para 68. Charter of Fundamental Rights of the European Union, O.J. C 364, 1-22. Note, however, that CJEU's reliance on Article 17 of the Charter has been criticised for being "very thinly reasoned": Griffiths, "Constitutionalising or harmonising? The Court of Justice, the rights to property and European copyright law" (2013) 38(1) EL Rev 65, 76.

${ }^{52}$ Case C-604/10 Football Dataco, cit., para 48.

${ }^{53}$ Ibid., para 52.
} 
Despite being a case concerning the interpretation of the Database Directive, the reasoning of the CJEU in Football Dataco appears extendable to the InfoSoc Directive and its set of exclusive rights. This is both because of the common objectives that the EU intended to achieve by adopting these two pieces of legislation, and also by reference in the judgment itself to CJEU decisions that relate to the interpretation of the InfoSoc Directive. ${ }^{54}$ Similarly to Luksan, Football Dataco suggests that Member States are not entitled to alter the scope of InfoSoc exclusive rights. In particular, this decision appears to imply that, following EU intervention, Member States would lose their competence to legislate in parallel to and provide conditions that differ from those set at the EU level.

\section{EU Pre-Emption and InfoSoc Exceptions and Limitations}

The InfoSoc Directive harmonised copyright exceptions and limitations, in the belief that - as with exclusive rights - differences among the laws of Member States had direct negative effects on the functioning of the internal market, and that such differences would have become more pronounced in view of the further development of cross-border exploitation of works. ${ }^{55}$ While the Directive purported to define exceptions and limitations more harmoniously, it was felt that their degree of harmonisation should both be based on their impact on the smooth functioning of the internal market ${ }^{56}$ and take account of the different legal traditions in Member States. ${ }^{57}$

Use of the term 'expressions or limitations' in Article 5 appears to go beyond the legacy of the language employed in international instruments. ${ }^{58}$ In her Opinion in Joined Cases C-457-460/11 VG Wort, ${ }^{59}$ Advocate General Sharpston clarified that a copyright limitation may be intended as something less than an exception. In any case, the catalogue of exceptions and limitations to InfoSoc exclusive rights is an

\footnotetext{
${ }^{54}$ Notably Cases C-5/08 Infopaq, cit., and C-393/09 Bezpečnostní softwarová asociace - Svaz softwarové ochrany v. Ministerstvo kultury [2010] ECR I-13971; and Joined Cases C-403/08 and C-429/08 Football Association Premier League, cit.

55 Recital 31.

${ }^{56}$ Ibid.

${ }^{57}$ Recital 32.

58 The expression 'exceptions and limitations' has been traditionally taken to reproduce the language employed in international copyright instruments (see, amongst others, Article 10 of the WIPO Copyright Treaty), on consideration that certain countries (eg, Belgium) are familiar with the term 'exceptions', other countries (eg, Germany and Spain) employ the term 'limits', others (eg Sweden and Greece) refer to 'limitations', others (eg, Italy, Portugal and UK) use completely different expressions altogether, and there are countries (eg, France) that do not use any term at all. See Sirinelli, Exceptions and limits to copyright and neighbouring rights (1999), available at tinyurl.com/p6mh9fm, 2.

${ }^{59}$ Joined Cases C-457-460/11 Verwertungsgesellschaft Wort (VG Wort) v. KYOCERA Document Solutions Deutschland GmbH and Others, Opinion of Advocate General Eleanor Sharpston delivered on 24 January 2013, para 37.
} 
exhaustive list (Recital 32) ${ }^{60}$ While the rationale of Article 5 requires a coherent application of the various exceptions and limitations, the Directive leaves Member States the option (the sole exception being temporary acts of reproduction) ${ }^{61}$ to provide for certain exceptions or limitations for such cases such as educational and scientific purposes, for the benefit of public institutions and archives, for the purpose of news reporting, quotations, use by people with disabilities, public security uses and uses in administrative and judicial proceedings. ${ }^{62}$ The non-mandatory nature of Article 5 exceptions and limitations has reinforced in some commentators the overall idea that the InfoSoc Directive has been "a total failure, in terms of harmonisation". 63

Article 5(2) lists a number of possible exceptions and limitations to the right of reproduction. Article 5(3) indicates the cases in which Member States may provide for exceptions or limitations to the rights of reproduction or communication and making available to the public. Despite use of the conjunction 'and' ("Member States may provide for exceptions or limitations to the rights provided for in Articles 2 and 3"), the optional nature of Article 5 list suggests that an exception or limitation pursuant to Article 5(3) may be provided to the right of reproduction and not also to the right of communication and making available to the public, and vice versa. In any case, pursuant to Article 5(4), a certain exception or limitation to the right of distribution appears admissible only where such exception or limitation is also provided with regard to the right of reproduction, and to the extent justified by the purpose of the authorised act of reproduction.

The general limit is that set by of Article 5(5), which intended to import the three-step test into EU law, and is directed at national legislators and courts alike. ${ }^{64}$ Exceptions ${ }^{65}$ should be limited to special cases and may not be applied in a way that is prejudicial to the legitimate interests of the rightholder or conflicts with the normal exploitation of his/her work or other subject-matter. ${ }^{66}$

\footnotetext{
${ }^{60}$ But $c f$. Article 5(3)(o), allowing Member States to provide for limitations or exceptions for certain uses of minor importance where limitations already exist under national law, provided that they concern only analogue uses and do not affect the free circulation of goods and services within the Community. According to van Eechoud and Others, Harmonizing European Copyright Law. The Challenges of Better Law Making (Kluwer Law International, 2009), 103, the grandfather clause in Article 5(3)(o) means that the directive does not unequivocally provide for a closed list of limitations. See also European Commission, "Public Consultation", cit., 16.

${ }^{61}$ Art. 5(1).

${ }^{62}$ European Parliament, 1997/0359(COD), Final Act 22 May 2001, available at tinyurl.com/pka55jx.

${ }^{63}$ Hugenholtz, "Why the Copyright Directive is unimportant", cit., 501. In the same sense, see also Janssens, "The issue of exceptions: reshaping the keys to the gates in the territory of literary, musical and artistic creation", in Derclaye (ed.) Research Handbook on the Future of EU Copyright, cit., 332 and bibliography cited therein. For similar criticisms, yet expressed at the proposal stage, see Hart, "The proposed directive for copyright in the information society: nice rights, shame about the exceptions" (1998) 20(5) EIPR 169, 169-170.

${ }^{64}$ Senftleben, Copyright Limitations, and the Three-Step Test: An Analysis of the Three-Step Test and EC Copyright Law (Kluwer Law International, 2004), 281.

${ }^{65}$ Limitations may be left aside here, if one agrees with AG Sharpston's understanding of Article 5.

${ }^{66}$ Recital 44.
} 


\subsection{The Debate around Article 5 Reform}

Discussion whether open-ended systems of exceptions and limitations or even the provision of a general fair use doctrine as it exists under Section 107 of the US Copyright Act should be preferred to closed systems of exceptions and limitations has become increasingly central to copyright reform projects, a notable example being Australia. ${ }^{67}$ Much of the debate about the merits of a fair use defence has focused on the themes of flexibility and certainty, and a fair use defence has been said to offer flexibility at the expense of certainty. ${ }^{68}$ However, empirical evidence suggests that a doctrine like US fair use may not necessarily generate legal uncertainties. Indeed, an analysis of judicial decisions on fair use by US courts has found that the extent to which lower courts are reversed by higher ones does not significantly diverge between copyright law and other areas of law in the US. ${ }^{69}$ Overall, the main concern is that closed systems of exceptions and limitations might inhibit innovation, while a legal environment like that resulting from Section 107 of the US Copyright Act might allow copyright exceptions be adjusted effectively to changing developments without additional legislation. ${ }^{70}$

Whether and how InfoSoc catalogue of exception and limitations should be reformed is being currently discussed broadly - at both the Commission ${ }^{71}$ and national levels ${ }^{72}-$, especially in light of widespread criticism that Article 5 would lack the flexibility needed to accommodate technological development. ${ }^{73}$ This follows especially from the consideration that Article 5 "lists 21 limitations and exceptions that Member States may provide for in their national laws, but does not allow exceptions beyond this "shopping list." 74

\footnotetext{
${ }^{67}$ See Australian Government - Australian Law Reform Commission, "Copyright and the Digital Economy” (2013), 59-98.

${ }^{68}$ See Burrell, "Reining copyright: is fair use the answer?” (2001) 4(2001) IPQ 361, 364-365.

${ }^{69}$ Beebe, “An empirical study of U.S. copyright fair use opinions, 1978-2005” (2008) 156(3) Univ Pa Law Rev 549, 574-575.

${ }^{70}$ Dnes, "Should the UK Move to a Fair-Use Copyright Exception?" (2013) 44(4) IIC 418, 419.

${ }^{71}$ See Commission of the European Communities, “Green Paper on Copyright in the Knowledge Economy”, Brussels, COM(2008) 466/3, 6-9; European Commission, Communication from the Commission to the European Parliament, the Council, the European Economic and Social Committee and the Committee of the Regions, "A Single Market for Intellectual Property Rights Boosting creativity and innovation to provide economic growth, high quality jobs and first class products and services in Europe", $\operatorname{COM}(2011) 287$ final, 11; European Commission, "Communication from the Commission on Content in the Digital Single Market”, COM(2012) 789 final, 5; Kroes, “The Commission's work on copyright reform”, 14 November 2013, available at tinyurl.com/n5df7u7.

72 As recent instances, see Gowers Review of Intellectual Property (2006), 66-68, and Digital Opportunity, A Review of Intellectual Property and Growth (2011), 42-46, in the UK; Mission "Acte II de l'exception culturelle". Contribution aux politiques culturelles à l'ère numérique - Tome I (2013), 36-37 in France; Modernising Copyright (2013), 72-75 and 89-97 in Ireland.

${ }^{73}$ See, amongst others, Hilty and Others, "European Commission - Green Paper. Copyright in the Knowledge Economy - Comments by the Max Planck Institute for Intellectual Property, Competition and Tax Law" (2008) Max Planck Institute for Intellectual Property, Competition and Tax Law Research Paper Series No 08/05, 8; Senftleben, "Bridging the differences between copyright's legal traditions - the emerging EC fair use doctrine" (2010) 57 JCopyrSocy 521, 528;

${ }^{74}$ Hugenholtz, "Law and technology. Fair use in Europe" (2013) 56(5) Communications of the ACM 26, 27.
} 
In parallel to this, both the Commission ${ }^{75}$ and some commentators have attempted to determine how flexibility in Article 5 may be enhanced. Amongst others, Hugenholtz and Senflteben have held the view that "the enumerated provisions [of the InfoSoc Directive] are in many cases categorically worded prototypes rather than precisely circumscribed exceptions, thus leaving the Member States broad margins of implementation". ${ }^{76}$ This said, and despite the inherently flexible nature of directives as a legal instrument, there have not been many attempts ${ }^{77}$ to determine whether the Directive actually allows significantly flexible implementations and whether this sort of flexibility might be overall a desirable goal for the EU and its Member States. If the primary objective of an EU intervention in the area of copyright exceptions and limitations was to remove market fragmentation, and provide a legal framework that favours EU competitiveness, this question may not be left unaddressed.

\subsection{Does the InfoSoc Directive Allow Flexible Implementations?}

Recital 32 expressly states that Member States should arrive at a coherent application of Article 5 exceptions and limitations. Contrary to relevant practice at the level of individual Member States (notably the UK) ${ }^{78}$, it is submitted that - except where expressly so provided by the Directive (eg Article 5(2)(c) which refers to "specific acts of reproduction" to be defined at the national level), the InfoSoc Directive may not allow Member States to alter the scope of the exceptions and limitations they have decided to import into national copyright regimes. An example may be Article 5(3)(b): from the wording of this provision, it appears doubtful that Member States may limit its applicability to certain works or specific disabilities. ${ }^{79}$

\footnotetext{
75 "[T] he formulation of certain of the limitations and exceptions is general enough to give significant flexibility to the Member States as to how, and to what extent, to implement them (if they decide to do so)." (European Commission, "Public Consultation", cit.,16).

${ }^{76}$ Hugenholtz - Sentleben, Fair Use in Europe. In Search of Flexibilities (2011), available at tinyurl.com/7e4gnoo, 2. In a similar sense, see also Hart, "The Copyright", cit., 59, and Dussolier, "The limitations and exceptions to copyright and related rights for libraries, research and teaching uses", in Triaille and Others, Study on the Application of Directive 2001/29/EC on Copyright and Related Rights in the Information Society (The 'InfoSoc Directive') (2013), available at tinyurl.com/q64a9q3, 248. To enhance flexibility in EU copyright, see also Article 5.5 of the Wittem Group's European Copyright Code (2010), as discussed by Hugenholtz, "The Wittem Group's European Copyright Code", in Synodinou (ed.) Codification of European Copyright Law: Challenges and Perspectives (Kluwer Law International, 2012), 351.

${ }^{77}$ A notable exception (albeit mainly from the perspective of the possible resulting benefits, rather than actual legal constraints), is Senftleben, Copyright Limitations, cit., 281, holding the view that the framework set out in Article 5 should be copied as precisely as possible: "By doing so, a further fragmentation of copyright law in the EU can be prevented. If all member states would literally reproduce the cases they wish to include in national law and subject these cases to the three-step test, a uniform framework would indeed be established."

${ }^{78}$ See below $s u b \$ 4.4$.

${ }^{79}$ Ibid.
} 
This conclusion follows especially from analysis of the language employed in Article 5, and consideration that national differences in the treatment of exceptions and limitations may be tolerated only in cases of minor importance, insofar that these do not adversely affect the functioning of the internal market. ${ }^{80}$

Overall, it would appear that, besides Article 5(3)(b), exceptions and limitations like those provided in Articles 5(2)(a), (b), (d) (e), and Articles 5(3)(d), (f), (h), (i), and (m) require Member States that have decided to import them into their national laws to reproduce the very language of the Directive. Even in those cases (Articles 5(3)(f), (h), (i), and (m)) where the conjunction 'or' is employed, this should be interpreted as exemplifying the possible uses of a work or other protected subject-matter, rather than setting distinct options.

Similarly to exclusive rights, an incoherent national drafting of exceptions and limitations would frustrate (or rather: have frustrated) the objectives that the EU intended to achieve by adopting the InfoSoc Directive, notably establishing a level playing field for copyright. Ultimately, this would be also tantamount to a breach of Member States' obligations under EU law, including the doctrine of pre-emption. As will be seen below, sub §4.3., this conclusion appears supported by the recent - yet scarcely (if at all) considered decisions in Cases C-510/10 TV2 Danmark and - prior to it (although perhaps less explicitly) - C-467/08 Padawan.

Article 5 also codifies a number of hypotheses in which the conjunction 'or' is used to indicate distinct options and purposes, as is the case of Article 5(2)(c), and Articles 5(3)(a), (c), (e), (g), (j), (k), (l), and (n). So, taking for instance the case of Article 5(3)(e $)^{81}$, it would seem that Member States have the choice whether to provide for a specific exception or limitation to the rights of reproduction and communication/making available to the public in respect of: (i) uses for the purposes of public security; (ii) uses to ensure the proper performance of certain proceedings which may be - disjunctively administrative, parliamentary, and/or judicial); (iii) uses to ensure the proper reporting of certain proceedings which may be - again, disjunctively - administrative, parliamentary, and/or judicial.

As the CJEU explained in Case C-145/10 Painer, in instances like that of Article 5(3)(e) Member States' discretion must be exercised within the limits imposed by EU law, including the principle of proportionality. ${ }^{82}$ In accordance with this principle, the measures that the Member States may adopt

\footnotetext{
${ }^{80}$ See especially Recitals 7 and 31.

81 "Member States may provide for exceptions or limitations to the rights provided for in Articles 2 and 3 in the following cases ... (e) use for the purposes of public security or to ensure the proper performance or reporting of administrative, parliamentary or judicial proceedings".

${ }^{82}$ Case C-145/10 Painer, cit., para 105.
} 
must be appropriate for attaining their objective and must not go beyond what is necessary to achieve it. ${ }^{83}$ Furthermore, "the discretion enjoyed by the Member States cannot be used so as to compromise the principal purpose of Directive 2001/29 which ... is to establish a high level of protection for, in particular, authors, which is crucial to intellectual creation. ${ }^{" 84}$ In addition, the exercise of that discretion must comply with the need for legal certainty for authors with regard to the protection of their works, ${ }^{85}$ as well as the general limit set by Article 5(5). ${ }^{86}$ Finally, held the Court, exceptions and limitations are a derogation from the general principle established by that directive, namely the requirement of authorisation from the copyright holder for the doing of any act restricted by copyright of a protected work. As such, they "must, according to settled case-law, be interpreted strictly." ${ }^{\circ 7}$

\subsection{The TV2 Danmark Decision and a New Insight into Padawan}

Case C-510/10 TV2 Danmark was a reference for a preliminary ruling from the Østre Landsret (Denmark), seeking clarification, among other things, as to the interpretation of Article 5(2)(d). This - among other things $-{ }^{88}$ provides for an exception to the right of reproduction "in respect of ephemeral recordings of works made by broadcasting organisations by means of their own facilities and for their own broadcasts." The referring court wished to know whether the expression 'by means of their own facilities' must be interpreted by reference to national or EU law. The CJEU responded by noting that the wording of Article 5(2)(d) is directly inspired by that of Article 11bis(3) of the Berne Convention. ${ }^{89}$ As already mentioned, although not a party to the Berne Convention, the EU is nevertheless obliged to comply with it, pursuant to Article 1(4) of the WIPO Copyright Treaty. ${ }^{90}$ Article 11 bis(3) of Berne expressly states that it is a matter for legislation in the countries of the Union to determine the regulations for ephemeral recordings made by a broadcasting organisation by means of its own facilities and used for its own broadcasts. That being so, by adopting the InfoSoc Directive, the EU exercised the competence previously devolved on the Member States in the area

\footnotetext{
${ }^{83}$ Ibid., para 106.

${ }^{84}$ Ibid., para 107.

85 Ibid., para 108.

${ }^{86}$ Ibid., para 110.

${ }^{87}$ Ibid., para 109.

${ }^{88}$ Article 5(2)(d) also envisages the possibility for Member States to allow the preservation of ephemeral recordings in official archives on the grounds of their exceptional documentary character.

${ }^{89}$ Case C-510/10 TV2 Danmark, cit., para 28.

${ }^{90}$ See above $s u b \$ 3.2$.
} 
of copyright. As a result, within the scope of that directive, the EU must be regarded as having taken the place of the Member States, which are no longer competent to implement the relevant stipulations of the Berne Convention. ${ }^{91}$ It is settled case law ${ }^{92}$ that, if a provision of EU law makes no express reference to the law of the Member States for the purpose of determining its meaning and scope, then - in compliance with the need for a uniform application of EU law and the principle of equality - the terms of such provision must be given an independent and uniform interpretation throughout the EU. The objective of the InfoSoc Directive was to harmonise certain aspects of the law on copyright and related rights in the information society, and ensure that competition in the internal market was not distorted as a result of differences in the legislation of Member States. This requires the elaboration of autonomous concepts of EU law:

“The European Union legislature's aim of achieving a uniform interpretation of the concepts contained in Directive 2001/29 is apparent in particular from recital 32 in the preamble thereto, which calls on the Member States to arrive at a coherent application of the exceptions to and limitations on reproduction rights, with a view to ensuring a functioning internal market." ${ }^{93}$

That being so:

\begin{abstract}
"[A]lthough it is open to the Member States ... to introduce an exception in respect of ephemeral recordings into their domestic law, an interpretation according to which Member States which, exercising that option afforded to them by European Union law, have introduced an exception of that kind, are free to determine, in an un-harmonised manner, the limits thereof, inter alia as regards the facilities used to make those ephemeral recordings, would be contrary to the objective of that directive as set out in the preceding paragraph, inasmuch as the limits of that exception could vary from one Member State to another and would therefore give rise to potential inconsistencies". ${ }^{94}$
\end{abstract}

In so concluding, the CJEU confirmed and made more explicit the implications of its earlier decision in Case C-467/08 Padawan. This was a reference for a preliminary ruling concerning - among other things the notion of 'fair compensation' in Article 5(2)(b), in particular whether this must be regarded as an autonomous concept of EU law which, as such, must be interpreted in a uniform manner in all Member

\footnotetext{
${ }^{91}$ Ibid.

${ }^{92}$ See, inter alia, Cases 327/82 Ekro BV Vee-en Vleeshandel v. Produktschap voor Vee en Vlees, [1984] ECR I-107, para 11; C-287/98 Grand Duchy of Luxemburg v. Berthe Linster and Others [2000] ECR I-6917, para 43; C-5/08 Infopaq, cit., para 27; and C-34/10 Oliver Brüstle v. Greenpeace eV, [2011] ECR I-9281, para 25.

${ }^{93}$ Case C-510/10 TV2 Danmark, cit., para 35.

${ }^{94}$ Ibid., para 36.
} 
States, irrespective of the Member States' right to choose their own system of collective rights management. The Court observed that neither Article 5(2)(b) nor any other provision in the InfoSoc Directive refer to the national law of the Member States as regards the concept of 'fair compensation' ${ }^{95}$ It concluded that:

\begin{abstract}
"[A]lthough it is open to the Member States, pursuant to Article 5(2)(b) of Directive 2001/29, to introduce a private copying exception to the author's exclusive reproduction right laid down in European Union law, those Member States which make use of that option must provide for the payment of fair compensation to authors affected by the application of that exception. An interpretation according to which Member States which have introduced an identical exception of that kind ... are free to determine the limits in an inconsistent and un-harmonised manner which may vary from one Member State to another, would be incompatible with the objective of [the InfoSoc] [D]irective". ${ }^{96}$
\end{abstract}

The decisions in TV2 Danmark and Padawan lead to the conclusion that, unless where the InfoSoc Directive leaves it to Member States to fine-tune the scope of certain exceptions and limitations, it is not possible for them to alter the scope of the exceptions and limitations that they have decided to transpose into their national regimes. In such cases Member States appear required to import the same substantive scope of the chosen exceptions and limitations. Hence, the InfoSoc Directive would be much less flexible than what has been hitherto understood. However this would not be necessarily to the detriment of maintaining (or restoring) a proper balance between exclusive rights and exceptions and limitations in the EU. On the contrary it could actually favour more liberal approaches to defining the scope of copyright protection. It is true that, on the one hand, Member States would be prevented from broadening the scope of exceptions and limitations beyond the wording of Article 5. On the other hand, Member States would be also prevented from restricting the language of exceptions and limitations. Although there appears to be no specific case law on this point, it is also possible to argue that, in certain situations, providing narrower exceptions or limitations than that which is allowed under Article 5 could be tantamount to a violation of fundamental rights under the Charter, notably freedom of expression ex Article $11^{97}$ or freedom to conduct a business ex Article $16 .{ }^{98}$ Overall a distinctive advantage of importing the (non-overly specific) language of Article 5 verbatim (where

\footnotetext{
${ }^{95}$ Case C-467/08 Padawan, cit., para 31.

${ }^{96}$ Ibid., para 36.

${ }^{97}$ As highlighted by Dashwood - Wyatt, Wyatt and Dashwood's European Union Law, $6^{\text {th }}$ edn (Hart Publishing, 2011), 367, Article 11 corresponds to Article 10 of the European Convention of Human Rights (ECHR) and entails any form and type of expression, including commercial expression. For recent applications of Article 10 to copyright cases, see the decisions of the European Court of Human Rights in Robert Ashby Donald and Others v. France, Appl. No. 36769/08, judgment of 10 January 2013, and Fredrik Neij and Another v. Sweden, Appl. No. 40397/12, judgment of 19 February 2013.

${ }^{98}$ See in particular Case C-510/10 TV2 Danmark, cit., para 57, but also Cases C-70/10 Scarlet Extended SA v. Société belge des auteurs, compositeurs et éditeurs SCRL (SABAM), [2011] ECR I-11959, para 46, and C-360/10 Belgische Vereniging van Auteurs, Componisten en Uitgevers CVBA (SABAM) v. Netlog NV, [not yet published], 16 February 2012, para 44.
} 
possible) would be that of allowing national courts to interpret exceptions and limitations in a way that would help accommodate new instances, especially those arising out of technological development.

\subsection{The Case of the $U K$}

The way the InfoSoc Directive has been transposed stands as a demonstration of the fact that Member States did not consider that they had any specific constraints as regards the language of the exceptions and limitations they decided to import into their own national laws. A notable example is the UK, which has transposed only certain exceptions, and has done so by adopting a language that is narrower than that employed by Article 5 .

Both the Gowers and Hargreaves Reviews criticised UK and EU legislative frameworks for exceptions and called for their reform. The Hargreaves Review found the enumerated list in Article 5 of Directive 2001/29/EC inadequate to accommodate technological change, ${ }^{99}$ and advised that the UK and the other Member States consider adopting a new mechanism at the EU level that would ensure built-in adaptability to future technologies. ${ }^{100}$ In parallel to this, similarly to the Gowers Review ${ }^{101}$, the Hargreaves Review recommended that the UK took fuller advantage of Article 5 exceptions and limitations, and in particular adopted specific exceptions for format shifting, parody, non-commercial research, and library archiving. In its response to the Review, UK Government agreed that the widest possible (non-derogable ${ }^{102}$ ) exceptions to copyright within the existing EU and international framework would be beneficial to the UK. ${ }^{103}$

In mid-2013, the UK Intellectual Property Office (IPO) published draft exceptions for technical review for people with disabilities, private copying, parody, criticism and review, public administration, data analysis for non-commercial research, education, research, libraries and archives. ${ }^{104}$ Besides proposed

\footnotetext{
${ }^{99}$ Digital Opportunity, cit., 43.

100 Ibid., 47.

${ }^{101}$ Gowers Review of Intellectual Property, cit., Recommendations 8-10b and 12, 6.

102 Whether Article 5 exceptions and limitations may be overridden by contractual agreements remains disputed: see Bechtold, “Directive 2001/29/EC", in Dreier - Hugenholtz (eds) Concise European Copyright Law (Kluwer Law International, 2006), 370371; and Aplin - Davis, Intellectual Property Law: Text, Cases and Materials, $2^{\text {nd }}$ edn (OUP, 2013), 203-204, who consider Article 5 omission "surprising".

${ }^{103}$ HM Government, "The Government Response to the Hargreaves Review of Intellectual Property and Growth ” (2011), 7-8 and 16.

104 These are available at tinyurl.com/kal2ld9. The amended exceptions are planned to come into force in April 2014: see Department for Business Innovation and Skills, "BIS Seventh Statement of New Regulation - Regulations covering January to June 2014" (2013), available at tinyurl.com/qjoqy7d, 6-7.
} 
exceptions for private copying, parody and data analysis for non-commercial research, ${ }^{105}$ all the other draft provisions are intended to broaden the scope of exceptions that already exist under UK law, but are in narrower terms than what is permitted under EU law. Considering for instance the case of proposed exceptions for people with disabilities, the Copyright Designs and Patents Act 1988 (CDPA) currently provides a number of exceptions (Sections 31A-F) allowing accessible versions of literary, dramatic, musical and artistic works be made for visually impaired people. UK Government intends to extend these exceptions "to include all types of disability that prevent someone from accessing a copyright work, and to all types of works. The aim of this is to help ensure that all people are able to access cultural materials, regardless of any disability they may have." 106 Article 5(3)(b) of the InfoSoc Directive allows Member States to provide for exceptions or limitations to the rights of reproduction, communication and making available to the public to allow uses, for the benefit of people with a disability, which are directly related to the disability and of a non-commercial nature, to the extent required by the specific disability. The language of the Directive is clear: this exception or limitation is intended for people with any disability and for any category of work, and does not appear to make any reference to national law. Applying the reasoning of the CJEU in Padawan and TV2 Danmark to Article 5(3)(b), it appears possible to conclude that an interpretation according to which the UK was entitled determine its limits thereof, inter alia as regards the understanding of 'disability', would be contrary to the objective - clearly stated in Recital $43^{107}$ - that the Directive intended to achieve by adopting this exception or limitation. This conclusion appears applicable to other exceptions whose scope UK Government is currently considering expanding. It is worth adding that, by transposing directly the full language employed in Article 5 selected exceptions and limitations, the UK would have avoided spending (considerable) time and resources discussing how to reform relevant CDPA provisions.

\section{Unharmonised Rights and Related Exceptions and Limitations}

This contribution has attempted to show that the InfoSoc Directive has harmonised certain exclusive rights and related exceptions and limitations in a way that might have left Member States with much less flexibility than has been traditionally understood. As a result the marge de manoeuvre for national initiatives should be understood as narrower. Subject to their own international obligations, Member States are however able to

\footnotetext{
${ }^{105}$ Contrary to the view expressed in the Hargreaves Review (Digital Opportunity, cit., 8), IPO considers that such an exception would be already permitted under EU law, in that it would fall within the scope of Article 5(3)(a): see tinyurl.com/lhf87me.

106 Intellectual Property Office, Disability exceptions (2013), available at tinyurl.com/oxg4d2p.

107 "It is in any case important for the Member States to adopt all necessary measures to facilitate access to works by persons suffering from a disability which constitutes an obstacle to the use of the works themselves, and to pay particular attention to accessible formats." According to von Lewinski - Walter, "Information Society Directive" in Walter - von Lewinski (eds.) European Copyright Law. A Commentary (OUP, 2010), 1046, this recital appears to go even beyond the provision of an exception or limitation, and may actually involve the provision of financial resources by Member States.
} 
legislate autonomously in respect of unharmonised rights, related exceptions, as well as neighbouring rights. Influential commentators hold the view that this would be the case - amongst others - of the right of adaptation. $^{108}$

\subsection{The Right of Adaptation under International and EU Laws}

Adaptation is usually understood as the transformation of a work into another form of expression that is not tantamount to a simple reproduction, ${ }^{109}$ eg making a film out of a novel, although "there is an unclear dividing line between what amounts to a reproduction of a work and what amounts to an adaptation of a work". ${ }^{110}$ At the international level it was only at the 1948 Brussels conference that adaptation was formulated as a self-standing right. Article 10 of the Berne Act 1886 considered adaptations as specific instances of unauthorised indirect appropriations of a literary or artistic work that, as such, would be considered an infringement of the right of reproduction. ${ }^{111}$ Article 12 of the Berne Convention states that authors of literary or artistic works shall enjoy the exclusive right of authorising adaptations, arrangements and other alterations of their works. However, the systematic approach of the Berne Convention does not require Union countries to do the same. As a result, there remain significant differences in national laws as to whether adaptations and other transformations are to be regarded as forms of reproductions (as is the case, for instance, in France and The Netherlands), or whether they are subject to a separate right (as is the case, for instance, in Italy, Germany and the UK). ${ }^{112}$ Above all, current formulation of Article 12 elicits reflection as to what its relationship with Article 9 Berne right of reproduction is. According to Ginsburg and Ricketson, the right of reproduction as per Article 9 is widely framed and includes reproductions of the nonoriginal kind that historically were covered by Article 12. These 'colourable imitations' may be excluded from Article 12, which should be interpreted simply as conferring the right to make derivative works of the kind referred to in Article 2(3). ${ }^{113}$

\footnotetext{
${ }^{108}$ See von Lewinski - Walter, "Information Society Directive" in Walter - von Lewinski (eds.) European Copyright Law, cit., 964 and 1479; Goldstein - Hugenholtz, International Copyright. Principles, Law, and Practice, $3^{\text {rd }}$ edn (OUP, 2013), 322; Bently, The Hargreaves Review of Intellectual Property and Growth. Exploring the Flexibilities available to UK Law (2011), available at tinyurl.com/lfljbcy, §§39-40; van Eechoud and Others, Harmonizing European Copyright Law, cit., 84; Ohly, "Economic Rights", in Derclaye (ed.) Research Handbook on the Future of EU Copyright, cit., 218; Hugenholtz - Senftleben, Fair use in Europe, cit., 26-27.

${ }^{109}$ von Lewinski, International Copyright Law and Policy (OUP, 2008), 143.

${ }^{110}$ Garnett - Davies - Harbottle, Copinger and Skone James on Copyright, 16 th $^{\text {edn }}$ (Sweet\&Maxwell, 2011), 514.

111 von Lewinski, International Copyright, cit, 142.

${ }^{112}$ See Ginsburg - Ricketson, International Copyright and Neighbouring Rights, $2^{\text {nd }}$ edn (OUP, 2006), 645; Goldstein - Hugenholtz, International Copyright, cit., 322.

${ }^{113}$ Ginsburg - Ricketson, International Copyright, cit., 655.
} 
The InfoSoc Directive does not contain any reference to the right of adaptation, which has been instead expressly harmonised in relation to databases (Article 5(b) of Directive 96/9/EC) and computer programs (Article 4(1)(b) of Directive 2009/24/EC). Therefore, the main question is whether Member States have retained their competence to define the right of adaptation in respect of literary and artistic works (these are the only works subject to Berne right of adaptation and, as such, are the only subject-matter for which possible EU constraints might subsist) other than databases and computer programs, as well as its related exception(s) and limitation(s).

As mentioned, Article 2 of the InfoSoc Directive does not define the concept of reproduction, ${ }^{114}$ so it may be uncertain whether adaptations may be considered a form of reproduction within this directive. Although the CJEU has stressed the need for a broad definition of this right, ${ }^{115}$ it appears possible to conclude that Member States have retained their competence to legislate independently with regard to the right of adaptation. The 1995 Green Paper (from which ultimately the InfoSoc Directive originated) defined the right of reproduction by referring to Article 9 of the Berne Convention ${ }^{116}$ and concluded that a future directive on copyright in the information society should define this right with the approach taken with regard to computer programs. ${ }^{117}$ Both Directive 96/9/EC and Directive 2009/24/EC refer to the rights of reproduction and adaptation as two distinct rights.

While Member States may be considered free to determine both the scope of their national right of adaptation and its related exceptions and limitations, this should be done not only in compliance with international law, but also in a manner that does not unduly affect the scope of InfoSoc exclusive rights. So, taking the specific case of exceptions or limitations to the right of adaptation, these would have to comply not just with the three-step test, but also be designed in a manner that would not transform them into further - and, as such, forbidden - exceptions (in disguise) to other exclusive rights, notably the right of reproduction. It descends that Member States would be free to legislate in relation to exceptions or limitations to the right of adaptation, but these ought to be intended narrowly, ie as limited to what can be considered as pure adaptations, not transformative uses of a work that nonetheless also involve its simple reproduction. ${ }^{118}$ For instance, while it is arguable that creating a play from a novel may fall exclusively within the scope of the right of adaptation, it may be more difficult to sustain that the same would happen in

\footnotetext{
${ }^{114}$ Case C-5/08 Infopaq, cit., para 31.

${ }^{115}$ Ibid., paras 41-42.

${ }^{116}$ Commission of the European Communities, “Green Paper on Copyright and Related Rights”, cit., 50.

117 Ibid., 51-52.

${ }^{118}$ Cf Modernising Copyright, cit., 54-55, 72, and 91, with regard to proposed marshalling, innovation and fair use exceptions, respectively.
} 
the case of an artist that - among other things - reproduced an artistic work in an altered form, $e g$ by adding new elements, or changing the contrast and colour. ${ }^{119}$

\section{What Happens if a Member State Has Implemented the InfoSoc Directive Incorrectly?}

In light of the analysis conducted above, it appears that the InfoSoc Directive would leave Member States limited freedom to legislate autonomously in respect of InfoSoc exclusive rights and related exceptions and limitations. The final question is whether the provisions of the InfoSoc Directive that concern exclusive rights and exceptions and limitations may be deemed sufficiently unconditional and precise so that one may rely upon them before the courts of a Member State that has failed to implement them correctly. The answer appears to be in the affirmative, in that Articles 2 to 5 (unless where otherwise provided) impose on Member States, in unequivocal terms, well-defined obligations as to the result to be achieved that is not coupled with any condition regarding application of the rule laid down therein. ${ }^{120}$

This interpretation has been recently confirmed by Advocate General Sharpston in her Opinion in Case C-351/12 OSA. ${ }^{121}$ This is a (pending) reference for a preliminary ruling from the Krajský soud v Plzni (Czech Republic) asking, among other things, whether Articles 3 and 5 (notably Article 5(2)(e), (3)(b) and (5)) of Directive 2001/29/EC are unconditional enough and sufficiently precise for a certain individual or organisation (a copyright collecting society in this case) to rely on them before national courts in case of incorrect transposition of the Directive. AG Sharpston observed that:

"First, when national courts apply domestic law, they are bound to interpret it, so far as possible, in the light of the wording and purpose of any relevant directive, in order to achieve the result sought by the directive. That obligation is inherent in the system of the Treaty on the Functioning of the European Union. It enables those courts to ensure the full effectiveness of EU law when they determine disputes within their jurisdiction.

\footnotetext{
${ }^{119}$ In the US a case similar to this has been recently held to be fair use: Seltzer v. Green Day and Others, No. 11-56573 $\left(9^{\text {th }}\right.$ Cir. 2013).

${ }^{120}$ See Case C-282/10 Maribel Dominguez v. Centre informatique du Centre Ouest Atlantique and Préfet de la région Centre, [not yet published], 24 January 2012, para 34, with regard to Directive 2003/88/EC of the European Parliament and of the Council of 4 November 2003 concerning certain aspects of the organisation of working time, O.J. L 299, 9-19.

${ }^{121}$ Case C-351/12 Ochranný svaz autorský pro práva k dílům hudebním, os (OSA) v. Léčebné lázně Mariánské Láznè as, Opinion of Advocate General Eleanor Sharpston, delivered on 14 November 2013.
} 
Only if such an approach is not possible - for example, if it would lead to an interpretation contra legem - is it necessary to consider whether a relevant provision of a directive has direct effect and, if so, whether that direct effect may be relied on against a party to the national dispute."122

The AG also stressed that it is for national courts to do whatever lies within their jurisdiction, eg taking the whole body of domestic law into consideration and applying the interpretative methods recognised by it, to ensure that Directive 2001/29/EC is fully effective, and thus achieve outcomes consistent with the objectives pursued by it. ${ }^{123}$ She concluded that an interpretation of national law that would be inconsistent with the Directive is not permissible. ${ }^{124}$

The AG did not state expressly what the legal consequences of incorrect implementations of the InfoSoc Directive would be. However, she appeared to agree with OSA's suggestion that this would be disapplication of incorrect national provisions. ${ }^{125}$ Thus, in the context of exclusive rights and certain (sufficiently detailed) exceptions and limitations, incorrect transposition of the Directive might entitle national courts to disapply national laws that, similarly to the Austrian law at stake in Luksan or the Danish exception for ephemeral recordings in TV2 Danmark, have gone astray from what the InfoSoc Directive requires. This conclusion is a direct derivation of the principle of pre-emption (notably 'rule' or 'obstacle' pre-emption in the categorisation provided above sub §2). Above all, AG Sharpston's interpretation stands as a confirmation that, contrary to national implementation practices, adoption of Directive 2001/29/EC has pre-empted national initiatives in the area of harmonised exclusive rights and related exceptions and limitations.

\footnotetext{
${ }^{122}$ Ibid., paras 44-45.

${ }^{123}$ Ibid, para 46, referring - amongst others - to Case C-106/89 Marleasing SA v. La Commercial Internacional de Alimentación SA, [1990] ECR I-4135.

${ }^{124}$ Ibid., para 47.

${ }^{125}$ Ibid., paras 38 and 43. See Case C-555/07 Seda Kücükdeveci v. Swedex GmbH \& Co. KG, [2010] ECR I-00365, para 56. See also Craig - de Búrca ${ }_{2}$ EU Law: Text, Cases, and Materials, $5^{\text {th }}$ edn (OUP, 2011), 193, and above, sub $\$ 2$.
} 